\title{
EXPANDING THE UNDERSTANDING OF HEALTH AS AN INTANTGIBLE GOOD TODAY
}

\author{
Lìga Mazure \\ Rezekne Academy of Technologies, Latvia
}

\begin{abstract}
In classical interpretation, health is defined as a subjective right to this intangible good, which is only characteristic of humans. However, it could be evaluated whether health as a relevant interest can be characteristic of any other subject, expanding the existing understanding of health. The modern legal system distinguishes between subjects with different levels of protection of their interests, i.e., the subjects of rights and the subjects of interests. And a trend is observed where health is also recognised as a category characteristic of the subjects of interests, adjusting the former understanding of the concept of health. Thus, by expanding the understanding of health, types of health can be distinguished according to the subject of interests, e.g., health of a legal person, health of a conceived person, etc., adapting the understanding of health to the criteria of the subject of interests. The research aim is to analyse the expansion of the understanding of health and suggest a division of the types of health in accordance with the modern legal system. The following primary research methods were used in the study: analytical, systemic, teleological.
\end{abstract}

Keywords: expansion of the understanding, health, human, legal system, subject of interests, types.

\section{Introduction}

In classical interpretation, health is defined as a subjective right to this intangible good, which is only characteristic of humans. However, nowadays, when the legal system is becoming more nuanced, directions for the expansion of the understanding of health are emerging which do not attribute health exclusively to humans.

From the analysis of the processes in the legal system, a characteristic category is observed for specific subjects of interests, which shows elements of the notion of health. Thus, types of health can be distinguished according to the subject of interests, thus expanding the understanding of health.

The Latvian legal system demonstrates clashes between the legal science, normative regulation and case law concerning the groundwork on the types of health. We need to create a uniform approach to the understanding and types of health, ensuring proper functioning of the legal system. 
The research aim is to analyse the expansion of the understanding of health and suggest a division of the types of health in accordance with the modern legal system. The following primary research methods were used in the study: analytical, systemic, teleological.

\section{Literature Review}

Literature, laws and regulations and legal practice materials were used in the research process. From the evaluation of the sources, it can be concluded that no comprehensive research on the types of health is found. The sources only outline some groundwork in this direction.

\section{Methodology}

Special legal science research methods were used in the research process: the semantic, grammatical, analytical, historical, comparative, systemic, and teleological method.

\section{Discussion}

Health as a relevant interest is protected. The legal system distinguishes between subjects with different levels of protection of their interests. Interest is a particular good of the subject, where three types of interest are distinguished: first, legally irrelevant interests, which have no legal protection; second, legally relevant interests, which are protected by law; third, subjective rights, where the legal norm includes significant interests, also creating a legal obligation for another person (Ten Haaf, 2017, pp.1108-1110; Mullins, 2019, p.96; Paul, 2007, pp.720-725; Kelch, 1999). And following this division of interests, subjects of rights and subjects of interests can be distinguished (Ten Haaf, 2017, p.1108). Thus, the specific scope of interests of the subjects of rights are characterized by absolute legal protection, where the legal protection of a previously undefined scope of interests of the subjects of interests depends on the ability to justify the significance of such interests, acquiring a relative character of legal protection. Interests exist independently from the state, where the state chooses which interests to protect (interest theory, Ihering) (Law Insider, 2020, pp.639-640). And it is not implausible that a currently irrelevant interest with time can acquire the character of a legally protected interest, with the change of value criteria in society. Undeniably, health is an important good, which falls within the content of any interest, including subjective rights and relevant interests.

This raises the question - what subjects have interests? First, it is determined that things cannot have interests (Ten Haaf, 2017, p.1115). Second, 
criteria for determining the subjects of interests are offered and evaluated identifiability of the subject, the ability to feel, its conative life, as well as the subject's obligatory emergence in the future if it does not yet exist (Ten Haaf, 2017, p.1114, 1116, 1118, 1119; Campbell, 2017). The analysis of these criteria results in, on the one hand, primary criteria for determining the subject of interests and establishing its legal status (identifiability, emergence at least in the future); on the other hand - additional criteria for weighing the importance of the subject of interests and expanding its legal status (ability to feel, conative life). It can thus be concluded that the subject of interests has no legal status of the subject of rights, and the legal status of the subject of interests is comprised of criteria with rather broad interpretation. Still, the subjects of interests have interests. And it can be evaluated whether health as a relevant interest in this intangible good can be characteristic of any other subject, expanding the existing understanding of health as a subjective right to this intangible good only characteristic of humans.

It is arguable whether a legal person has a relevant interest in health as an intangible good. Until now, a principle has been established that a legal person could not have an intangible good that is only characteristic of a natural person (LR Augstākās tiesas Judikatūras un zinātniski analītiskā nodaļa, 2019, 3.1.pk.; European Court of Human rights, 2011, point 22), and health was consolidated as only characteristic of humans. However, the significance of the prevalent theory that recognises real existence of a legal person and attributes the same qualities to it as to a natural person (Čakste, 2017, 41.lpp.) is nowadays growing. A trend is observed in the legal system where legal entities are more widely recognised as subjects with personality (Mazure, 2014, 103.lpp.; Rozenbergs, 2003; Krimināllikums, 1998, VIII.1.nod.; Krons, 1940; Civillikums, 1992a, 387.p.; Civillikums, 1993a, 1635.p.; Bitāns, 2006). It is also stated that a legal person can also have intangible goods (LR Augstākās tiesas Senāta Civillietu departaments, 2019; LR Augstākās tiesas Senāta Civillietu departaments, 2008; LR Augstākās tiesas Judikatūras un zinātniski analītiskā nodaļa, 2019, 3.1.pk.), only the understanding of intangible good of a natural and legal person is different (LR Augstākās tiesas Judikatūras un zinātniski analīiskā nodaḷa, 2019, 3.1.pk.; European Court of Human rights, 2011, point 22). Also, intangible goods of legal persons have already been discussed in the legal science as having the characteristics of the criterion of health -as an effective course of all processes, i.e., achieving goals and wellbeing of employees in the work environment (Xenidis \& Theocharous, 2014, pp.563-565). Thus, a trend is observed promoting the recognition of health for legal persons as well, adapting the understanding of health to the principle of a legal person. The health of a legal person is defined as its internal organisational functioning, which also affects the wellbeing of its employees, as well as the ability to undertake the 
civil obligations, to develop and reach its goals in society. Despite the fact that a legal person is the subject of rights in civil-law relations, it is characterised by health as a relevant interest of a subject of interests, which is not yet secured in the normative regulation.

Traditionally, health is understood as an intangible good characteristic of humans. However, this understanding is narrowed down by attributing health to a specific period of the person's development, i.e., from the person's birth until their death. Such an approach is justified by the fact that a person's legal capacity appears at birth, and legal relevance appears by mere fact of birth, which is proven by the registration of the fact in the registry of births (Civillikums, 1993a, 1406.p.; Torgāns et al., 1998, 20.1pp.; Civil Code, 1804, a.16; Civilstāvokḷa aktu reǵistrācijas likums, 2012, V nod.; LR Augstākās tiesas Senāta Administratīvo lietu departaments, 2006; LR Administratīvā apgabaltiesa, 2007); and legal capacity ends with death - the death of the brain (Kārtība, kādā veicama smadzeņu un bioloǵiskās nāves fakta konstatēšana un miruša cilvēka nodošana apbedīšanai, 2007, 2.-7.pk.) or presumption of death, when the person is legally declared dead (Civillikums, 1993b, 377., 378.p.; Civilprocesa likums, 1998, 286.p.2., 3.d.). Thus, health is only attached to the legal capacity period of the person as a subject of rights rather than the person's entire period of life.

However, there is a period of a person's life when health is not directly attributed to a person in a legal sense. This is the situation of a conceived but yet unborn person ("nasciturus" - "that shall hereafter be born" (Grimm, 2003, 66 s.), "conceptus" - "conceived" (Sanfillipo, 2002, 38 s.)). A person is considered to be conceived from the fusion of gametes until the human being is born, when the baby has fully detached from the mother's flesh, creating parallels with natural appearance of fruit at the moment of detachment, where the cutting of the umbilical cord is not an obligatory prerequisite (Mazure, 2014, 66.lpp.; Balodis, 2007, 74., 75.lpp.; Kennedy \& Grubb, 1998, p.190; Larenz \& Wolf, 1997, S.123; Civillikums, 1992b, 856.p.). Ambiguity lies in the following circumstance. On the one hand, a conceived human being is not recognised as the subject of rights because this human being does not have a legally recognised legal personality in a broad sense (Kennedy \& Grubb, 1998, p.190). On the other hand, however, some rights of a conceived person are still protected (for example, a conceived person has a recognised capacity to inherit (Civillikums, 1992a, 386.p.), parents can appoint guardians for their expected children in a testament (Civillikums, 1993b, 223.p.1.d.) etc.), but the normative regulation does not specify or give a general approach - what type of rights are protected and what the scope of this protection is.

Nowadays, a trend is observed in the change of approach regarding the connection between a conceived person and health. On the one hand, a 
conceived person at this point is considered an integral part of the mother's body until detachment, because substances required for sustaining life and development are received through the mother, making the conceived person completely dependent on the expectant mother (Kennedy \& Grubb, 1998, p.189, 193). On the other hand, the legal science sees an increasingly convincing opinion that a conceived person is not to be seen as part of the expectant mother's body. Two main arguments are made: 1) a conceived person is genetically unique (McHale, Fox, \& Murphy, 1997, p.705; Liholaja, 2004, 28.lpp.) and thus different from the expectant mother's genetic characterization; 2) unlike an expectant mother's body part, the embryo develops into a being which is able to exist independently, i.e., the "potentiality argument" (J.Harris) (Liholaja, 2004, 28.lpp.; Sîlis, 2006, 106.lpp.). Thus, premises are found for the expansion of the understanding and scope of the protection of rights of a conceived person.

Considering that a conceived person is not a legally irrelevant fact (Schulman, 2013, p.11, 12), attempts have been observed to recognise health as characteristic of a conceived person too. Two approaches emerge. First, the protection of the rights of a conceived person is included in the legal personality of their parents (Robinson, 2018, p.25, 26; Campbell, 2017) where the health of a conceived person is defined as a protected interest of the parents. Second, the health of a conceived person is valued as an independent protected interest where the protection of the health of a conceived person follows from their right to life, considering the close interrelation, albeit with a different scope of the protection of the right to life for born and unborn persons (Eiropas Cilvēktiesību un pamatbrīvību aizsardzības konvencija, 1950, 2.p.1.d.; LR Satversme, 1993, 93.p.; Bundesverfassungsgericht des Deutschlands, 1975; Bundesverfassungsgericht des Deutschlands, 1993). Influenced by these approaches and the opportunities provided by medical science, the normative regulation provides for medical treatment of a conceived person (Ministru Kabinets, 2018; Simič, 2018, p.256, 257), i.e., improvement of the health of a conceived person. Thus, the legal practice attempts to protect the health of a conceived person using derived legal reasoning, supporting the understanding of health as being characteristic of a conceived person as well.

The modern legal system needs to specify and formalise the legal status of a conceived person and the understanding of their health in the context of medical treatment. Although a conceived person is not a subject of rights in accordance with the existing principles of legal capacity, still they correspond to the features of a subject of interests. This is also reinforced by two processes observed in the legal system. First, a future person is discussed, which has not been conceived yet but could be conceived in the future, seeing them as a subject of interests and even trying to protect them in the normative regulation 
(Ten Haaf, 2017, p.1104, 1106; Ten Haaf, 2016, p.1, 14) (e.g., in the German Civil Code when setting limits for proxyconsent to sterilisation of a patient, the interests of a yet unconceived person are also taken into account (Civil Code, 1896, § 1905(1)). Second, an opinion has been expressed that following the principle of symmetry of logic (Dmitriev et al., 2006, s.130) one criterion needs to exist which can be used to determine the moment of emergence and termination of a person as a subject of rights. If the criterion used to determine the death of a person is brain death (Kārtîba, kādā veicama smadzeṇu un biologiiskās nāves fakta konstatēšana un miruša cilvēka nodošana apbedīšanai, 2007, 2.-7.pk.), then the beginning of life should be the moment when the brain starts functioning, i.e., at the $6^{\text {th }}$ week of embryonic development (Apinis, 1998, 732., 733.lpp.), which can be medically observed. And the health possessed by the conceived person is to be valued as an independent relevant interest of the subject of interests. If we take into account that according to the direction of implementation of health, a person's health is divided into internal health, i.e., the ability to perform the function of life and the bodily and mental functions medically related to it; and external health, i.e., the ability to socialise and individually fulfil oneself (Mazure, 2020, p.45), then a conceived person can only have internal health, adapting the understanding of health to the principles of a conceived person. Thus, the health of a conceived person can be defined as proper functioning of the cells, tissues, and organs, which ensures its viability.

When evaluating the understanding of health, it can be found that nowadays health is also explained from the point of view of the interests of society, recognising health as a category characteristic of society. Considering that society in general can have interests and even rights, the sense of public health is also used, which denotes the health of society (Paul, 2007; Kramer, 2016; Atbrecht, Higginbotham, Connor, \& Ellis, 2017; Müller, Ganten, \& Larisch, 2014, S.A1900; Shevchenko, 2004, s.267). Thus health is understood not only as a private good characteristic of a specific individual subject, but also as a public good (Müller, Ganten, \& Larisch, 2014, S.A1901; Büchs, \& Koch, 2019, p.162; Australian Institute of Health and Welfare, 2014, p.1) characteristic of a specific set of subjects. And as soon as this set of subjects can be identified, it is a recognised category characteristic of this set, which has the features of health.

The definition of public health is derived from the types of public health, which highlight its most significant, interrelated principles. Firstly, according to the scope of the members of the set of subjects, public health is divided into the health of all society (see: Epidemiologiiskās drošības likums, 1997, 3.p.1.d.8.pk.; Svalastog, Donev, Kristoffersen, \& Gajovič, 2017) and the health of a specific social group (see: Freeman, 1961, p.278; Welfare, 2019; Lock, Last, \& Dunea, 2006; The Ottawa Charter for Health Promotion, 1986), which is characteristic 
of at least two subjects in a mutual relationship and describes these subjects as an aggregate. Secondly, according to the direction of implementation of health, public health is divided into internal health of the set of subjects, which is the sum of individual health of separate subjects of the set, and into external health of the set of subjects, because the features of the set are not related exclusively to the features of its members (Freeman, 1961, p.278; Shevchenko et al., 2004, c.273) and in the set of subjects external health describes the quality of its existence and development, as well as the quality of interaction between its subjects. Thus, public health can be defined as the effectiveness of relationships of a social group or the members of the whole society and their mutual interaction, which describes the organisation and development of a social group or society, also including the sum of individual health of the members of specific social groups or the whole society.

Nowadays a direction is observed where health is also recognised as a category characteristic of animals, expanding the existing understanding of health. And the legal evaluation of the idea of animal health is carried out.

On the one hand, based on the normative regulation, an animal is a live physical thing which belongs to an owner or can be an unowned thing, for example, a wild animal (Civillikums, 1992b, 841., 842.p.1.d., 931., 932.-935.p.; Civillikums, 1993a, 2365.p.; Grūtups et al., 1996, 23.lpp.; Rozenfelds, 2000, 96.lpp.; Sinaiskis, 1996, 235.lpp.; Torgāns et al., 1998, 643., 644.lpp.), and an animal cannot be a participant in legal relations and has neither rights nor obligations (Torgāns, 2014, 515.lpp.; Sinaiskis, 1996, 29.lpp.). Thus, normative regulation does not provide for the relevant interest of an animal in health as an intangible good.

However, on the other hand, regardless of the philosophical attempts to single out the superior status of a human being due to its unique ability to value its life and create the future based on reason and free will (Sîlis, 2006, 111., 113., 114.lpp.; Kūle\&Kūlis, 1996, 628.lpp.), nowadays the legal meaning of animals is growing. This can be justified as follows. Human beings are not owners of other beings but constitute only one of these beings (Dibifē, 1992, 19.lpp.), and all live things, based on the extended interpretation of natural rights, have the right to equality (Ulpian) (Jevola) and the right to respect (I.Kant) (Kelch, 1999). And special legal categories are growing in the legal systems, i.e., the importance of animals, granting them a certain legal status and valuing it higher than a thing (Kūle \& Kūlis, 1996, 631.lpp.; Callicott, 1980, p.311). This is why it is recognised that animals have interests (Campbell, 2017; Jackson, 2013, p.625) and their specific rights can be determined, rather than only regulating human behaviour in society for the protection of animals (Čakste, 19XX, 12., 13.lpp.) - the right not to be a property, the right to life, the right to be respected (Svece, 2019), the right to be free from pain (Kelch, 1999). 
Thus, prerequisites are formed in the legal system for the expansion of the understanding of animal status.

The situation is disputable - while the basic principles of the legal meaning of animals are still discussed within the legal system, animal health is already protected by normative regulation. The idea of the protection of animal health is enshrined at the international (Global Animal Law Association, 2018; World Organisation for animal health, 2015, s.6), the European (The European Parliament and of the Council, 2016; The European Parliament and of the Council, 2010), and the national level (Dzivnnieku aizsardzības likums, 1999, Preambula, 5.p.1.d., 2.d.2.pk., 7.p.; Veterinārmedicīnas likums, 2001, 1.p.7.pk., 15.p.1.d., 2.d.; Animal health act, 1981; Animal health protection, 1926; Animal health act, 2014; Animal health act, 2009; Animal health and protection act, 1989; Animal health act, 1988; Animal health act, 2010), having also created for this purpose the World Organisation for Animal Health, which consists of 181 member countries (The World Organisation for Animal Health, 2020) and having recognised from ancient times the existence of one medicine for people and animals, which also includes veterinary medicine (Zinsstag, Schelling, Waltner-Toews, \& Tanner, 2011, p.149). Attempts have also been observed to define animal health as an individual condition which includes physical, mental, and social factors and which is aimed at coping with pathologies (Global Animal Law Association, 2018), and where this definition has been created as an analogy to the current definition of human health.

The arguments show that in the modern legal system animals are recognised as subjects of interests where their status already outweighs only the characteristics of a thing but cannot yet be legally equated to the status of the subject of rights, and an animals' relevant interest - health - is crucial to its life and survival. Animal health can be defined as an analogy to human health, adapting this definition to the understanding of an animal. Thus, animal health can be explained as proper functioning of the animal's organs, which ensures its ability to live and the ability to adapt to the ecosystem (to survive), also considering the impact (both positive and negative) of society on the ecosystem.

Here emerges another expansion of the understanding of health, attributing health to the ecosystem. An ecosystem is a functional system which includes populations found within a specific territory and the inanimate environment of their existence (Baldunčiks \& Pokrotniece, 1999, 180.lpp.). The terms used in the normative regulation - "rehabilitation of natural resources", "environmental quality" (Vides aizsardzības likums, 2006, 1.p.15.pk., 2.p.1.d.), "environmental health” (Epidemiologiskās drošības likums, 1997, 3.p.1.d.1.pk.) - leading to believe that the health of the ecosystem (nature) is implied.

Ecosystem health is related to animal and public health, which manifests in two ways. On the one hand, ecosystem health is separate from animal health 
(Huffman, 1992, p.55; Callicott, 1988, p.164), which is a category of separate natural elements; and ecosystem health is separate from public health, where both together form the health of the planet (Prescott \& Logan, 2019, p.102; Callicott, 1988, p.164). It is noteworthy that initially in Ancient times nature and society were viewed as a whole, where human beings were part of nature, blending with it; in the Medieval Period, with the consolidation of religion and its principle that nature was created by God, the importance of a human being had grown, and people separated themselves from nature; and nowadays people contrast themselves with nature on the basis of the power of technology available to them (Kūle \& Kūlis, 1996, 629., 630.lpp.). Thus, the relationship between nature and society has a growing split, which is confirmed by the historical development of this relationship.

On the other hand, ecosystem health is interrelated with public health where two aspects can be emphasised. First, the health of the ecosystem and society have a mutual effect on each other, where society does certain harm to the health of the ecosystem (Kruse, 2019; Prescott \& Logan, 2019, p.99; Zinsstag et al., 2011, p.150, 151, 153; Callicott, 1980, p.325; Bambra, Smith, \& Pearce, 2019, p.36; Albrecht et al., 2017; Rapport, 1989; Tountas, 2009, p.191), unlike the ecosystem in relation to society. Thus, society has an obligation to preserve, protect, and restore the ecosystem (Rio Declaration on environment and development, 1992, Pr.7). And second, health of the ecosystem is independent from society (Rapport, 1989), whereas the opposite cannot be stated. It can thus be concluded that ecosystem health has formed and consolidated as a separate and independent category.

To evaluate the legal nature of the ecosystem, it is recognised as a subject of interests, considering its independence. This approach is also indirectly supported by the principle that existence and preservation of the ecosystem is in the interest of the next generations of society (Büchs \& Koch, 2019, p.155, 163; Callicott, 1988, p.163). There is a fascinating and unprecedented case when a river as a separate element of nature was even granted the legal status of a subject of rights with a set of rights, obligations and responsibility as recognition of the moral value of that specific river for those specific peoples -the Maori (Te Awa Tupua Act, 2017, s.12; Kurki, 2019, p.1, 3, 11). Although such practice, most likely, is not supported in the legal system, it still supports the growing trend of the legal meaning of the ecosystem in the modern day.

There have been several attempts to define ecosystem health, which is difficult, in order to achieve a comprehensive result. Important principles of attempted definition can be noted, which have been included in the definition of the ecosystem - good condition of the environment (Kruse, 2019), a good functioning system (Burkhard, Müller, \& Lill, 2008), activity of the ecosystem, organisation and adaptability according to objective scientific criteria (Lu et al., 
2015; Rapport, 1995), ability to solve problems (Rumpelsberger, 2012, S.18). Thus, ecosystem health can be defined as the quality condition of nature assessed according to science-based criteria, as well as a mutually functioning system of the elements of nature aimed at the existence, preservation, and regeneration of the ecosystem.

Thus, health is understood in a broader sense, not only as an intangible good characteristic of humans, and the reasons for the expansion of such understanding are aimed in three directions - a more nuanced legal understanding of a human being, attribution of human features to social formations, and the growth of the legal meaning of the ecosystem and its elements, which leads to the idea of the types of health.

\section{Research Results and Conclusions}

1. Regardless of the fact that health is described as a subjective right to this intangible good characteristic only of humans, nowadays directions for the expansion of the understanding of human health are emerging which do not relate it exclusively to humans. For specific subjects of interests, a category characteristic of them can be established, which has the features of the notion of health.

2. With the legal system becoming more nuanced, types of health can be distinguished according to the subject of interests they describe, thus expanding the understanding of health. When giving a definition of the health of a subject of interests, it has to be adapted to the principles of the understanding of that specific subject of interests.

3. Apart from human health, the following other types of health can be distinguished: 1) health of a legal person; 2) health of a conceived person; 3) public health; 4) animal health; 5) ecosystem health. Each type of health is given a definition, which is included in the suggested draft section of the normative regulation.

The Medical Treatment Law is to be supplemented with Section $3^{2}$ as follows:

"Section $3^{2}$.

(1) The health of a legal person is the functioning of its internal organisation, which also affects the wellbeing of its employees, as well as the ability to undertake the civil obligations, develop and reach its goals in society.

(2) The health of a conceived person means proper functioning of its cells, tissues, and organs, which ensures its viability.

(3) Public health is the effectiveness of relationships of a social group or the members of the whole society and their mutual interaction, which 
describes the organisation and development of a social group or society, also including the sum of individual health of the members of a specific social group or the whole society.

(4) Animal health means proper functioning of the organs of the animal, which ensures its ability to live and the ability to adapt to the ecosystem, also considering the impact of society on the ecosystem.

(5) Ecosystem health is the quality condition of nature assessed according to science-based criteria, as well as a mutually functioning system of the elements of nature aimed at the existence, preservation, and regeneration of the ecosystem."

\section{References}

Albrecht, G.A., Higginbotham, N., Connor, L., \& Ellis, N. (2017). Social and cultural perspectives on ecology and health. In: International encyclopedia of public health (Second edition), 551-556. Doi: doi.org/10.1016/B978-0-12-803678-5.00414-8.

Animal health act. (2014). The act (SBC 2014 Chapter 16) of the British Columbia (Canada). Retrieved from https://www.bclaws.gov.bc.ca/civix/document/id/complete/statreg/14016\#part1.

Animal health act. (2010). The statute of Zambia (South Africa). Retrieved from https://zambialaws.com/principal-legislation/animal-health-act.

Animal health act. (2009). The act (S.O. 2009, Chapter 31) of Ontario (Canada). Retrieved from https://www.ontario.ca/laws/statute/09a31.

Animal health act. (1988). Chapter A-11.1 of the statutes of Prince Edward Island (Canada). Retrieved from https://www.princeedwardisland.ca/sites/default/files/legislation/a-11-1animal_health_act.pdf.

Animal health act. (1981). Public general act (1981 c. 22) of England, Wales, Scotland. Retrieved from https://www.legislation.gov.uk/ukpga/1981/22.

Animal health and protection act. (1989). The Chapter 15 of the statutes of Nova Scotia (Canada). Retrieved from https://nslegislature.ca/sites/default/files/legc/statutes/ animalhe.htm.

Animal health protection. (1926). Chapter (7 USC 109) of the United States Code. Retrieved from https://uscode.house.gov/view.xhtml?req=granuleid\%3AUSC-prelim-title7chapter109\&edition=prelim.

Apinis, P. (1998). Cilvēeks: Anatomija, fiziologijia, patoloğijas pamati. Rīga: Jāṇa sēta, 800 lpp.

Australian Institute of Health and Welfare. (2014). Australia's health 2014, 14, 576 p. Doi: $10.25816 / 5$ ec1e412.

Baldunčiks, J., \& Pokrotniece, K. (1999). Svešvārdu vārdnīca: vairāk nekā 15000 citvalodu cilmes vārdu un terminologisku vārdkopu. Rīga: Jumava.

Balodis, K. (2007). Ievads civiltiesībās. Rīga: Zvaigzne ABC, 383 lpp.

Bambra, C., Smith, K.E., \& Pearce, J. (2019). Scaling up: The politics of health and place. Social Science \& Medicine, 232, 36-42. Doi: doi.org/10.1016/j.socscimed.2019.04.036.

Bitāns, A. (2006). Gaidāms nemantiskā (morālā) kaitējuma lomas pieaugums. Dienas bizness/ Saldo, 7(34). 
Mazure, 2021. Expanding the Understanding of Health as an Intantgible Good Today

Bundesverfassungsgericht des Deutschlands. (1993). Die Entscheidung, BVerfGE 88, 203. Schwangerschaftsabbruch II, 28.Mai. Von: http://www.servat.unibe.ch/dfr/bv08 8203.html.

Bundesverfassungsgericht des Deutschlands. (1975). Die Entscheidung, BVerfGE 39, 1. Schwangerschaftsabbruch I, 25.Feb. Von: http://www.servat.unibe.ch/dfr/bv 039001.html.

Burkhard, B., Müller, F., \& Lill, A. (2008). Ecosystem health indicators. In: Encyclopedia of ecology, 1132-1138. Doi: doi.org/10.1016/B978-008045405-4.00312-8.

Büchs, M., \& Koch, M. (2019). Challenges for the degrowth transition: The debate about wellbeing. Futures, 105, 155-165. Doi: doi.org/10.1016/j.futures.2018.09.002.

Callicott, J.B. (1980). Animal liberation: A triangular affair. Environmental Ethics, 2, 311338. Doi: doi.org/10.5840/enviroethics19802424.

Callicott, J.B. (1988). Animal liberation and environmental ethics: Back together again. Between the Species, 4, 163-169. Doi: https://doi.org/10.15368/bts.1988v4n3.1.

Campbell, K. (2017). Legal rights. In: The Stanford encyclopedia of philosophy (Winter Edition), Edward N. Zalta (ed.). Retrieved from https://plato.stanford.edu/archives/ win2017/entries/legal-rights/.

Civil Code. (1804). Code of France. Retrieved from www.lexinter.net?ENGLISH/ civil_code.htm.

Civil Code. (1896). Code of Germany. Retrieved from www.gesetze-iminternet.de/englisch_bgb/englisch_bgb.html\#BGBengl_000G1.

Civillikums. (1993a). Ceturtā daḷa. Saistîbu tiesības. LR likums. LR Saeimas un Ministru Kabineta Zinotājs, 14.janv., 1.

Civillikums. (1993b). Pirmā daḷa. G̦imenes tiesības. LR likums. LR Saeimas un Ministru Kabineta Zinotājs, 10.jūn., 22/23.

Civillikums. (1992a). Otrā daḷa. Mantojuma tiesības, LR likums. LR Saeimas un Ministru Kabineta Zinotājs, 30.jūl., 29.

Civillikums. (1992b). Trešā daḷa. Lietu tiesības. LR likums. LR Saeimas un Ministru Kabineta Zinotōjjs, 30.jūl., 29.

Civilprocesa likums. (1998). LR likums. Latvijas Vēstnesis, 3.nov., 326/330.

Civilstāvokḷa aktu reğistrācijas likums. (2012). LR likums. Latvijas Vēstnesis, 14.dec., 197.

Čakste, K. (2017). Civiltiesības: Lekcijas. Raksti. Rīga: Zvaigzne ABC, 358 lpp.

Čakste, K. (19XX). Civiltiesības. Rīga, [b.i.].

Dibifē, Ž. (1992). Antikulturālas pozīcijas. Kentaurs XXI, 2.

Dmitriev, Ju.A. et al. (2006). Medicinskoe pravo. Moskva: Jelit, 496 s.

Dzīvnieku aizsardzības likums. (1999). LR likums. Latvijas Vēstnesis, 29.dec., 444/445.

Eiropas Cilvēktiesību un pamatbrīvību aizsardzības konvencija. (1950). Starptautiskais tiesību akts, 4.nov. Pieejams: http://www.echr.coe.int/NR/rdonlyres/56D2C838-7133-40108D00-99BE58570B95/0/LatvianLetton.pdf.

Epidemioloǵiskās drošības likums. (1997). LR likums. Latvijas Vēstnesis, 30.dec., 342/345.

European Court of Human rights. (2011). Case of Uj v. Hungary (Application Nr. 23954/10), 19.07.2011. Judgment. Retrieved from file://C:/Users/user/Downloads/001-105715.pdf.

Freeman, R.B. (1961). Impact of publicē health on society. Public Health Reports, 4, 277280. Retrieved from https://pubmed.ncbi.nlm.nih.gov/13701645/.

Global Animal Law Association. (2018). UN Convention on animal health and protection (UNCAHP). Retrieved form https://www.globalanimallaw.org/downloads/FolderUNCAHP.pdf.

Grimm, D.D. (2003). Lekcii po dogme rimskogo prava. Moskva: Zercalo, 496 s. 
Grūtups, A. et al. (1996). Latvijas Republikas Civillikuma komentāri: Īpašums. Rīga: Mans İpašums, $231 \mathrm{lpp}$.

Huffman, J.L. (1992). Do Species and Nature Have Rights? Pub. Land L. Rev., Vol.13, 51, 51-76. Retrieved from https://scholarship.law.umt.edu/cgi/viewcontent.cgi?article= $1232 \&$ context $=$ plrlr.

Jackson, E. (2013). Medical law: text, cases, and materials. Oxford: Oxford University Press. Jevola, Ju. Tajnaja priroda estestvennogo prava. Iz: http://www.pravaya.ru/book/19/4391.

Kelch, T.G. (1999). The role of the rational and the emotive in a theory of animal rights. B.C. Envtl. Aff. L. Rev., Vol.27, 1. Retrieved from https://lawdigitalcommons.bc.edu /ealr/vol27/iss1/2.

Kennedy, I., \& Grubb, A. (1998). Principles of medical law. Oxford: Oxford University Press, 868 p.

Kramer, M. H. (2016). In Defense of the Interest Theory of Right-Holding: Rejoinders to Leif Wenar on Rights. The University of Cambridge. Retrieved from http://www.law.cam.ac.uk/ssrn/.

Krons, M. (1940). Testamenta izpildītājs. Tieslietu Ministrijas Vēstnesis, 1.

Krimināllikums. (1998). LR likums. Latvijas Vēstnesis, 8.jūlijs, 199/200.

Kruse, M. (2019). Ecosystem health indicators. In: Encyclopedia of ecology (Second edition), Vol.1, 407-414. Doi: doi.org/10.1016/B978-0-12-409548-9.11200-X.

Kurki, V. (2019). Are Legal Positivism and the Interest Theory of Rights Compatible? Retrieved from dx.doi.org/10.2139/ssrn.3393798.

Kūle, M., \& Kūlis, R. (1996). Filosofija. Rīga: Burtnieks, 653 lpp.

Larenz, K., \& Wolf, M. (1997). Allgemeiner Teil des Bürgerlichen Rechts. München: Beck, $1021 \mathrm{~S}$.

Law Insider. (2020). Juridical concepts and jural analysis legal rights and duties, 616-684. Retrieved from https://www.lawinsider.com/documents/PsCQHu8MY8.

Liholaja, V. (2004). Aborts: slepkavība vai...? Latvijas Universitātes Raksti: Juridiskā zinātne, 667.

Lock, S., Last, J.M., \& Dunea, G. (2006). The Oxford Companion to Medicine (3 ed.). Oxford: Oxford University Press. Retrieved from: https://www.oxfordreference.com/ search?q=health+definition\&searchBtn=Search\&isQuickSearch=true.

LR Administratīvā apgabaltiesa. (2007). Spriedums lietā Nr.A1748-04/6 AA43-0401-07/9, 10.apr.

LR Augstākās tiesas Judikatūras un zinātniski analītiskā nodaḷa. (2019). Goda un cieņas civiltiesiskā aizsardzība. Tiesu prakses apkopojums (2000.-2018.), 47. Pieejams: http://at.gov.lv/lv/tiesu-prakse/tiesu-prakses-apkopojumi/civiltiesibas.

LR Augstākās tiesas Senāta Administratīvo lietu departaments. (2006). Spriedums lietā Nr.SKA-8, 17.janv.

LR Augstākās tiesas Senāta Civillietu departaments. (2019). Spriedums lietā Nr.SKC-40/2019 (C30291615), 10.jūl.

LR Augstākās tiesas Senāta Civillietu departaments. (2008). Spriedums lietā Nr.SKC458/2008 (C28107006), 10.dec.

LR Ministru kabinets. (2007). Kārtība, kādā veicama smadzeṇu un biologiskās nāves fakta konstatēšana un miruša cilvēka nodošana apbedīšanai. Ministru Kabineta noteikumi Nr.215, 27.marts. Latvijas Vēstnesis, 11.apr., 59.

LR Ministru Kabinets. (2018). Mātes un bērna veselības uzlabošanas plāns 2018.2020.gadam. Rīkojums Nr.259, 6.jūn. Latvijas Vēstnesis, 2018.8.jūn., Nr.113.

LR Satversme. (1993). LR pamatlikums. Latvijas Vēstnesis, 1.jūl., 43. 
Mazure, 2021. Expanding the Understanding of Health as an Intantgible Good Today

Lu, Y., Wang, R., Zhang, Y., Su, H., Wang, P., Jenkins, A., Ferrier, R.C., Bailey, M., \& Squire, G. (2015). Ecosystem health towards sustainability. Ecosystem Health and Sustainability, 1, 1-15. Doi: 10.1890/EHS14-0013.1.

Mazure, L. (2014). Pacienta griba un tās civiltiesiskā aizsardzība. Rēzekne: RA Izdevniecība, 350 lpp.

Mazure, L. (2020). Types of human health. Socrates, 3(18), 43-48.

McHale, J., Fox, M., \& Murphy, J. (1997). Health Care Law: Text, Cases and Materials. London: Sweet \& Maxwell, 947 p.

Mullins, R. (2019). Rights, roles and interests. Journal of Ethics and Social Philosophy, Nov., Vol.16, 2, 95-115. Doi: https://doi.org/10.26556/jesp.v16i2.398.

Müller, R., Ganten, D., \& Larisch, J. (2014). Public Health: Gesundheit ist mehr als Medizin. Dtsch Arztebl, 111(44), A1900-A1903. Von: https://www.aerzteblatt.de/archiv/ 163282/Public-Health-Gesundheit-ist-mehr-als-Medizin.

Paul, M. (2007). Rights. Arch Dis Child, Aug., 92(8), 720-725. Doi: http://dx.doi.org/ 10.1136/adc.2005.091629.

Prescott, S.L., \& Logan, A.C. (2019). Planetary health: From the wellspring of holistic medicine to personal and publice health imperative. Explore, Vol.15, 2, 98-106. Doi: 10.1016/j.explore.2018.09.002.

Rapport, D.J. (1995). Ecosystem health: More than a metaphor? Ecosystem Health, Vol.4, 4, 287-309. Retrieved from www.jstor.org/stable/30301563.

Rapport, D.J. (1989). What constitutes ecosystem health? Perspectives in Biology and Medicine, Vol.33, 1, 120-132. Doi: doi.org/10.1353/pbm.1990.0004.

Rio Declaration on environment and development. (1992). General Assembly of the United Nations, Conference on environment and development (Rio de Janeiro, 3-14 June). Retrieved from https://undocs.org/en/A/CONF.151/26/Rev.1(vol.I).

Robinson, R. (2018). The legal nature of the embryo: legal subject or legal object? PER/PELJ, 21-31. Doi: dx.doi.org/10.17159/1727-3781/2018/v21:0a2914.

Rozenbergs, J. (2003). Vainas institūts juridiskās personas kriminālatbildībā. Latvijas Universitātes Raksti, 657, 75-82.

Rozenfelds, J. (2000). Lietu tiesības. Rīga: Zvaigzne ABC, 296 lpp.

Rumpelsberger, K. (2012). Gesund ist, wer nicht krank ist? Subjektive Gesundheitsvorstellungen oberösterreichischer Hausärzte und ihre gegenwärtige und zukünftige Rolle. Universität Bielefeld, Dissertation. Von: https://pub.unibielefeld.de/download/2498340/2498351/RumpelsbergerDruckvorl.pdf.

Sanfillipo, Ch. (2002). Kurs rimskogo chastnogo prava. Moskva: BEK, 370 s.

Schulman, M. (2013). The nasciturus non - fiction, 47. Doi: dx.doi.org/10.2139/ssrn.2261847.

Shevchenko, Ju.L., et al. (2004). Filosofija mediciny. Moskva: GJuTAR-MED, 480 c.

Simič, J. (2018). The protection of nasciturus within the civil lae. Pravni zapisi, God.IX, br.2, 255-270. Doi: 10.5937/pravzap0-19193.

Sinaiskis, V. (1996). Latvijas civiltiesību apskats. Lietu tiesības. Saistību tiesības. Rīga: Latvijas Republikas Tieslietu ministrijas Tiesiskās informācijas centrs, 246 lpp.

Sīlis, V. (2006). Dzīvas būtnes, cilvēki un personas (Dž.Harisa nošķīrums). No Sīle, V., Biomedicinnas ètika (101-117). Rīga: Rīgas Stradiña universitāte.

Svalastog, A.L., Donev, D., Kristoffersen N.J., \& Gajovič, S. (2017). Concepts and definitions of health and health-related values in the knowledge landscapes of the digital society. Croat Med J., 58(6), 431-435. Doi: 10.3325/cmj.2017.58.431.

Svece, A. (2019). Dzīvnieku un vides ètika. Latvijas Universitāte, semināra lekciju kurss. Nepublicēts. 
Te Awa Tupua Act. (2017). Public Act Nr.7 of New Zealand. Retrieved from https://www.legislation.govt.nz/act/public/2017/0007/latest/whole.html.

Ten Haaf, L. (2016). Future persons and legal persons: The problematic representation of the future child in the regulation of reproduction. Laws, 5, 10-16. Doi: 10.3390/laws5010010.

Ten Haaf, L. (2017). Unborn and future children as new legal subjects: an evaluation of two subject oriented approaches - the subject of rights and the subject of interests. German Law Journal, Vol. 18, 05, 1092-1119. Doi: https://doi.org/10.1017/S2071832 200022264.

The European Parliament and of the Council. (2016). Regulation 2016/429 on transmissible animal diseases and amending and repealing certain acts in the area of animal health (“Animal Health Law”). Retrieved from http://data.europa.eu/eli/reg/2016/429/oj.

The European Parliament and of the Council. (2010). Directive 2010/63/EU on the protection of animals used for scientific purposes. Retrieved from http://data.europa.eu/eli/dir/ 2010/63/oj.

The Ottawa Charter for Health Promotion. (1986). First International Conference on Health Promotion, Ottawa. Retrieved from: https://www.who.int/healthpromotion/conferences/ previous/ottawa/en/.

The World Organisation for Animal Health. (2020). An international organization. Retrieved from https://www.ivsa.org/partners/world-organization-for-animal-health-oie/.

Torgāns, K. et al. (1998). Latvijas Republikas Civillikuma komentāri: Ceturtā daḷa. Saistību tiesības. Rīga: Mans Īpašums.

Torgāns, K. (2014). Saistību tiesības: mācību grāmata. Rīga: Tiesu namu aǵentūra, 590 lpp.

Tountas, Y. (2009). The historical origins of the basic concepts of health promotion and education: the role of ancient Greek philosophy and medicine. Health Promotion International, Vol. 24, 2, 185-192. Doi: 10.1093/heapro/dap006.

Veterinārmedicīnas likums. (2001). LR likums. Latvijas Vēstnesis, 16.maijs, 75.

Vides aizsardzības likums. (2006). LR likums. Latvijas Vēstnesis, 15.nov., 183.

Welfare. (2019). Dictionary.com. Retrieved from: https://www.dictionary.com /browse/welfare.

World Organisation for animal health. (2015). Recommendations of Third OIE Global conference on aquastic animal health: Riding the wave to the future (Ho Chi Minh City, Vietnam, 20-22 January). Retrieved from https://www.oie.int/en/conferences-events/alloie-world-conferences/presentationsrecommendations/.

Zinsstag, J., Schelling, E., Waltner-Toews, D., \& Tanner, M. (2011). From „one medicine” to „one health” and systemic approaches to health and well-being. Preventive Veterinary Medicine, 101, 148-156. Doi: 10.1016/j.prevetmed.2010.07.003.

Xenidis, Y., \& Theocharous, K. (2014). Organizational health: Definition and assessment. Procedia Engineering, 85, 562-570. Doi: https://doi.org/10.1016/j.proeng.2014.10.584. 